The International Journal of
Assessment
and Evaluation

Role of Formative Assessment in Improving Students' Motivation, Engagement, and Achievement A Systematic Review of Literature 


\section{EDITOR}

Bill Cope, University of Illinois at Urbana-Champaign, USA

Mary Kalantzis, University of Illinois at Urbana-Champaign, USA

\section{ACTING DIRECTOR OF PUBLISHING}

Jeremy Boehme, Common Ground Research Networks, USA

\section{EDITORIAL ASSISTANT}

Kortney Sutherland, Common Ground Research Networks, USA

\section{ADVISORY BOARD}

The Advisory Board of The Learner Research Network recognizes the contribution of many in the evolution of the Research Network. The principal role of the Advisory Board has been, and is, to drive the overall intellectual direction of the Research Network. A full list of members can be found at

https://thelearner.com/about/advisory-board.

\section{PEER REVIEW}

Articles published in The International Journal of Assessment and Evaluation are peer reviewed using a two-way anonymous peer review model. Reviewers are active participants of The Learner Research Network or a thematically related Research Network. The publisher, editors, reviewers, and authors all agree upon the following standards of expected ethical behavior, which are based on the Committee on Publication Ethics (COPE) Core Practices. More information can be found at

https://cgnetworks.org/journals/publication-ethics.

\section{THE INTERNATIONAL JOURNAL OF ASSESSMENT} AND EVALUATION

https://thelearner.com

ISSN: 2327-7920 (Print)

ISSN: 2327-8692 (Online)

https://doi.org/10.18848/2327-7920/CGP (Journal)

First published by Common Ground Research Networks in 2020

University of Illinois Research Park

2001 South First Street, Suite 202

Champaign, IL 61820 USA

$\mathrm{Ph}:+1-217-328-0405$

https://cgnetworks.org

The International Journal of Assessment and Evaluation

is a peer-reviewed, scholarly journal.

\section{COPYRIGHT}

(C) 2020 (individual papers), the author(s)

(C) 2020 (selection and editorial matter),

Common Ground Research Networks

All rights reserved. Apart from fair dealing for the purposes of study, research, criticism, or review, as permitted under the applicable copyright legislation, no part of this work may be reproduced by any process without written permission from the publisher. For permissions and other inquiries, please contact cgscholar.com/cg_support.

\section{Crossref}

Common Ground Research Networks, a member of Crossref

\section{ARTICLE SUBMISSION}

The International Journal of Assessment and Evaluation publishes biannually (June, December).

To find out more about the submission process, please visit $\mathrm{https}$ ://thelearner.com/journals/call-for-papers.

\section{ABSTRACTING AND INDEXING}

For a full list of databases in which this journal is indexed, please visit https://thelearner.com/journals/collection.

\section{RESEARCH NETWORK MEMBERSHIP}

Authors in The International Journal of Assessment and Evaluation are members of The Learner Research Network or a thematically related Research Network. Members receive access to journal content. To find out more, visit

https://thelearner.com/about/become-a-member.

\section{SUBSCRIPTIONS}

The International Journal of Assessment and Evaluation is available in electronic and print formats. Subscribe to gain access to content from the current year and the entire backlist. Contact us at cgscholar.com/cg_support.

\section{ORDERING}

Single articles and issues are available from the journal bookstore at https://cgscholar.com/bookstore.

\section{OPEN RESEARCH}

The International Journal of Assessment and Evaluation is Hybrid Open Access, meaning authors can choose to make their articles open access. This allows their work to reach an even wider audience, broadening the dissemination of their research. To find out more, please visit https://cgnetworks.org/journals/open-research.

\section{DISCLAIMER}

The authors, editors, and publisher will not accept any legal responsibility for any errors or omissions that may have been made in this publication. The publisher makes no warranty, express or implied, with respect to the material contained herein. 


\title{
Role of Formative Assessment in Improving Students' Motivation, Engagement, and Achievement: A Systematic Review of Literature
}

\author{
Ruth Nanjekho Wafubwa, ${ }^{1}$ Doctoral School of Education, University of Szeged-Hungary
}

\begin{abstract}
There is an increasing focus on formative assessment as education systems all over the world try to incorporate 21 st-century skills in their curriculums. Formative assessment has been considered one of the best approaches to teaching and assessing 21st-century competencies, which are crucial in addressing the current economic challenges. This review of thirty-eight empirical studies was done to find out how the key strategies of formative assessment have been conceptualized and their effect on students' motivation, engagement, and achievement. The analysis revealed that some strategies like the use of discussion have not been studied empirically. Other strategies such as learning intentions, success criteria, and selfassessment have only been used to a lesser extent. The analysis showed a positive influence of formative assessment strategies on students' motivation, engagement, and achievement. The results of this analysis provide a roadmap in the advancement of the theory of formative assessment and direction for future inquiry.
\end{abstract}

Keywords: Formative Assessment Strategies, Motivation, Engagement, Achievement

\section{Introduction}

$\mathrm{F}$ ormative assessment is an instructional process that involves continuous gathering, analyzing, and reflecting on evidence to make informed judgments and enhance student learning (Black and Wiliam 2009; Wiliam 2011). Formative assessment (assessment for learning) has gained prominence in the past few decades after the seminal work of Black and Wiliam (1998). However, the efficacy of formative assessment has been questioned by some researchers as it is reflected in several meta-analyses (e.g., Dunn and Mulvenon 2009; Kingston and Nash 2011; Briggs et al. 2012; Hendriks, Scheerens, and Sleegers 2014).

The gains of formative assessment as delineated by Black and Wiliam (1998) were critiqued (Dunn and Mulvenon 2009) basing on the method applied and the study context. Some of the methodological issues cited included the application of insufficient measured variables, unrestricted prediction of the examiner, uncontrolled precision of treatment, and use of unsuitable statistical units of inquiry. The concept of formative assessment has also not been well appreciated by some researchers. There have been claims that formative assessment is restricted in breadth and its utilization and hence reduced to classroom tests used for monitoring students' progress (Swaffield 2011; Torrance 2012). The inconsistency in the description of formative assessment practices was also pointed out by Dann (2014). According to Bennett (2011), defining formative assessment as a tool or a process is an oversimplification. Despite the issues surrounding the concept and efficacy of formative assessment, significant studies have reported the benefits of formative assessment (e.g., Anderson and Palm 2017; Ozan and Kincal 2018).

\section{Theoretical Background}

Formative assessment in the learning process was visualized by Black and William (2009) in terms of five key strategies that are expected to be attained through three negotiators.

\footnotetext{
${ }^{1}$ Corresponding Author: Ruth Nanjekho Wafubwa, Budapesti Ut 7, Educational Science, University of Szeged, Szeged, 6728, Hungary. email: wafubwa.ruth.nanjekho@edu.u_szeged.hu
} 


\section{The Three Negotiators (Agents)}

The three negotiators are the teacher, peer, and the learner who collaborate in the process of learning. Among the three negotiators, the teacher takes the center stage in the learning process. The crucial responsibility of the teacher is to help learners breach the learning gap between their current state and where the teacher wants them to be (Black and Wiliam 2009). The teacher is thus continuously involved in identifying learning goals for the learners and identifying where they are concerning those goals. The purpose of closing the gap is attained through prompt, definite, and remedial feedback; adjustments to instruction; and a supportive peer engagement process (Hattie and Timperley 2007; Shute 2008).

Teachers' roles emphasize setting clear goals, ensuring explicit features of success, providing constructive feedback, and supporting peer and self-reflection (Boud and Falchikov 2007; Spiller 2012). The learners have to take responsibility by also reflecting on a series of questions that would enable them to close the learning gap. By so doing, learners develop self-assessment skills which are crucial for life-long learning (Taras 2010; Leach 2012). A peer as an agent in the process of learning plays a critical role in developing judgment skills through an effective feedback mechanism.

\section{Key Strategies of Formative Assessment}

The five key strategies advanced by Black and William (2009) are described as follows:

1. Explicating and sharing learning targets and the basis for success. This strategy involves explicating, communicating, and comprehending intentions of learning and the criteria that define success (Brookhart 2011). Therefore, teachers are expected to clearly articulate the intended learning outcomes or lesson objectives so that learners get a better understanding of what is expected of them. Wiliam (2011) noted that teachers, learners, and peers should jointly break down this strategy into several standards for success.

2. Setting up constructive classroom discussions and other learning tasks. The focus of this strategy is on eliciting evidence of achievement which mostly takes the form of questioning. This strategy revolves around the teacher finding out where the learners are in their learning progress, so they can know the kind of evidence to collect (Wiliam 2011).

3. Providing feedback that moves learners forward. Research has shown that good feedback influences achievement in the most robust way (Hattie and Timperley 2007; Havis 2016). After researching formative assessment, Nicol and MacFarlane-Dick (2004) suggested seven concepts of quality feedback as involving reflection, dialogue, standards, learning opportunities, information to students, motivation, and information to teachers. Black and Wiliam (2009) noted that teachers could effectively provide feedback by the use of comments only as opposed to grading students.

4. Motivating students as teaching resources for one another. This strategy involves peer assessment, whereby students are involved in collaborative learning to improve performance. Wiliam (2011) noted that peer assessment geared towards improvement rather than evaluation could be more productive than when students interact directly with a teacher. Wiliam (2011) further noted that students benefit more because they work towards a common goal which enhances motivation and that thinking together enhances clarity of concepts. He (Wiliam 2011) suggested strategies of peer assessment like peer evaluation of homework using the rubric created by the teacher, student feedback on other students after instruction, and peers preparing and presenting their reviews to their group.

5. Motivating students to own their learning. This strategy appeals to students' motivation to learn. Wiliam (2011) observed that students are more likely to put effort into a task that they are interested in. Students will thus own their learning if they engage in self-regulatory processes like planning, monitoring, and evaluating which are also indicators of metacognitive skillfulness (Veenman 2011). The feedback that 
enables students to move forward is crucial if students have to actively construct their knowledge. Wiliam (2011) noted that students could not be owners of their learning without incorporating other strategies of formative assessment like feedback and sharing of learning objectives and success standards.

\section{Current Study}

The meta-analysis and reviews on the effect of formative assessment have mainly focused on achievement outcomes. Other effects are yet to be fully exploited. Cauley and McMillan (2010) described formative assessment as having a great influence on student motivation and achievement because students can focus on progress through on-going assessment, get meaningful feedback, and concretely see how they can improve. Moss, Brookhart, and Long (2011) used the metaphor of a windmill to envision the process of formative assessment and its effects. They (Moss, Brookhart, and Long 2011) related the way a windmill deliberately exploits the power of moving air to produce energy to the way the formative assessment process helps students to deliberately exploit the workings of their minds to initiate motivation to learn. Formative assessment should, therefore, be seen as multidimensional, and a focus on only one aspect can be misleading.

The current review focuses on how the strategies of formative assessment (Black and Wiliam 2009) have been applied in the studies and the effects the strategies have on students' achievement, engagement, and motivation. The current review is done systematically so that every aspect of formative assessment is given undivided attention. Unlike the previous reviews which have looked at formative assessment generally, this review seeks to find out how each of the formative assessment strategies has been conceptualized and used in research. The main aim of the review is to find out the aspects of formative assessment that have been under-researched and form a basis for future research. Specifically, the following questions guided the review:

1. How frequently has the formative assessment strategies been studied?

2. How do formative assessment strategies affect students' motivation, engagement, and achievement?

\section{Review Method}

\section{Procedure}

The approach taken in this review was a stepwise process that entailed composing research questions, specifying search terms, choosing databases, searching the literature, composing inclusion criteria, and extracting data (Popay et al. 2006).

\section{Databases and Search Terms}

The current thematic review synthesized studies on how formative assessment improves students' motivation, engagement, and achievement in secondary schools. The studies in the context of high schools and the middle schools were considered under secondary schools. The students' age range was generally from 12 to 18 years. Three databases (ERIC, EBSCO, and ELSEVIER) were used to identify studies. Some more papers were hand-searched using the Google Scholar search engine. Search terms that were used included "formative assessment or assessment for learning or formative feedback" with "motivation," "engagement," "secondary schools," "high school," or "middle school."

\section{Criteria for Study Inclusion}

The following guidelines were used to gauge the studies that would be considered for review: (1) the study had to be described as formative assessment (FA) or assessment for learning (AfL); (2) the study had to include empirical data and contain at least one of the five strategies of formative assessment; (3) participants belonged to secondary education set up; (4) the study 
must have been published between 2015 to 2019; (5) the study had to show the effect of formative assessment; (6) the study must have undergone a peer review and published in international journals; and (7) the study must be published in English. Unpublished work, such as master theses and conference papers, were not considered in this study.

\section{Data Extraction, Analysis, and Coding}

The initial search identified 832 records which were further narrowed down after going through a quality check. Some of the considerations for the quality check were as follows: the clarity of the research objective; clear research approach; clarity of the context of research; well-described methods and justifications; clear analysis procedure; clarity in the presentation of the results; and the relevance of the study. After assessing for eligibility, the final synthesis included thirty-eight studies. The studies were analyzed thematically based on the strategies of formative assessment. Key features from the articles were appropriately coded and used in the analysis. These key features include (1) authors and the year of publication; (2) study description; (3) sample characteristics; (4) research design and instruments used; and (5) main findings.

\section{Findings and Discussion}

The initial search of the databases identified 832 records, and thirteen more records were identified via the Google Scholar search engine. After eliminating duplicates, 544 studies were obtained. The second screening based on the level of the study left 105 studies. Further screening based on the quality check excluded fifty-nine studies from the records, leaving fortysix articles for eligibility assessment. Further examination of the full document led to the elimination of eight articles that did not fully focus on secondary education but included primary (elementary) and university levels. Finally, thirty-eight articles were deemed suitable for the final analysis. Out of the thirty-eight articles, two (5.3\%) focused on learning intentions and/or success criteria; seven (18.4\%) articles focused on feedback; eight (22.2\%) articles focused on the peer and self-assessment, while twenty-one $(56.3 \%)$ articles focused on formative assessment as a whole. In total, the literature review resulted in thirty-eight articles that were analyzed, and the results are presented in Tables 1 to 4.

\section{Learning Intentions (LI) and Success Criteria (SC)}

Two studies focusing on learning intentions and/or success criteria were obtained from the search process (see Table 1). Crichton and McDaid (2016) investigated teachers' and students' perceptions regarding the use of LI and SC within lessons. The second study by Krijgsman et al. (2019) focused on the importance of goal clarification and its relation to feedback. Crichton and McDaid (2016) observed that both teachers and students recognized the importance of LI and SC, especially during revisions. Students, however, felt that these strategies were rarely discussed in the classrooms, and teachers too expressed concerns about the implementation challenges. Therefore, the teachers felt the need for training on how to implement LI and SC in their lessons.

The study by Krijgsman et al. (2019) focused on goal clarification which is the same as clarifying LI and feedback. The study suggested the importance of goal clarification in feedback and need satisfaction. These two studies seem to suggest that the formative assessment strategy of sharing LI and SC has not been implemented in schools despite the suggested benefits.

Table 1: Studies on Learning Intentions (LI) and Success Criteria (SC) $(\mathrm{N}=2)$

\begin{tabular}{|c|c|c|c|c|c|}
\hline & Author & Study Description & Sample Characteristics & $\begin{array}{c}\text { Design and } \\
\text { Instruments }\end{array}$ & Main Findings \\
\hline 1 & $\begin{array}{c}\text { Crichton and } \\
\text { McDaid (2016) }\end{array}$ & $\begin{array}{c}\text { Teachers and } \\
\text { students' perceptions }\end{array}$ & $\begin{array}{c}20 \text { teachers and 20 } \\
\text { students; Scotland }\end{array}$ & Qualitative & $\begin{array}{c}\text { LI and SC strategies are } \\
\text { not implemented }\end{array}$ \\
\hline 2 & $\begin{array}{c}\text { Krijgsman et al. } \\
(2019)\end{array}$ & $\begin{array}{c}\text { Teachers' lesson } \\
\text { variability }\end{array}$ & $\begin{array}{c}570 \text { students; } \\
\text { Netherlands }\end{array}$ & Quantitative & $\begin{array}{c}\text { Goal clarification } \\
\text { affects process feedback }\end{array}$ \\
\hline
\end{tabular}

Source: Wafubwa 


\section{Appropriate Feedback}

A total of seven studies on feedback were reviewed (see Table 2). These studies were quantitative, and two used a quasi-experimental approach (Cutumisu and Schwartz 2018; Pinger et al. 2018a); two studies used a mixed design (Kyaruzi et al. 2018, 2019) while three only used a survey approach (Jónsson, Smith, and Geirsdóttir 2018; Van der Kleij 2019; Vattøy and Smith 2019).

While feedback is regarded as having the greatest influence on achievement (Hattie 2008), only two intervention studies examined the impact of feedback on students' achievement. Pinger et al. (2018a) studied the effectiveness of feedback which showed a positive influence on the students' achievement and their interest in mathematics. The intervention study by Cutumisu and Schwartz (2018) also revealed improved performance in students who engaged with critical feedback. Kyaruzi et al. (2019) focused on the impact of students' perceptions of their mathematics teachers, and the study revealed that feedback use predicted students' performance only to a small extent. Studies by Jónsson, Smith, and Geirsdóttir (2018) and Van der Kleij (2019) focused on the comparison between teachers' and students' perceptions regarding feedback. Both studies revealed differing perceptions between teachers and students with teachers having high perceptions as compared to students. Kyaruzi et al. (2018) indicated that the quality of feedback was positively predicted by teachers' perceptions of formative assessment while Vattøy and Smith's (2019) study revealed that students perceive their teachers' feedback to be more useful when they are informed of learning goals.

Analysis of studies on feedback has shown that effective feedback can improve students' motivation and achievement. It is worth noting that most studies focused on teacher and student perceptions. Only two studies, one in the USA (Cutumisu and Schwartz 2018) and one in Europe (Pinger et al. 2018a), used an experimental approach to investigate the effect of feedback on learning outcomes. A similar observation was realized in the meta-analysis by Van der Kleij, Feskens, and Eggen (2015); only six experimental studies done between 1968 to 2012 in secondary education settings met the criteria for inclusion in the analysis.

Table 2: Studies on Appropriate Feedback $(\mathrm{N}=7)$

\begin{tabular}{|c|c|c|c|c|c|}
\hline & Author & Study Description & Sample & Design & Main Findings \\
\hline 1 & $\begin{array}{l}\text { Jónsson, Smith, and } \\
\text { Geirsdóttir (2018) }\end{array}$ & $\begin{array}{c}\text { Perception of } \\
\text { teachers and students }\end{array}$ & $\begin{array}{l}56 \text { teachers and } 234 \\
\text { students; Iceland }\end{array}$ & Quantitative & $\begin{array}{l}\text { Teachers had higher } \\
\text { perceptions than students }\end{array}$ \\
\hline 2 & $\begin{array}{c}\text { Kyaruzi et al. } \\
(2018)\end{array}$ & $\begin{array}{l}\text { Effect of teachers' } \\
\text { perceptions }\end{array}$ & $\begin{array}{c}54 \text { mathematics } \\
\text { teachers; Tanzania }\end{array}$ & $\begin{array}{l}\text { Mixed } \\
\text { Method }\end{array}$ & $\begin{array}{c}\text { Feedback quality predicts } \\
\text { perceptions }\end{array}$ \\
\hline 3 & Van der Kleij (2019) & $\begin{array}{l}\text { Perceptions of } \\
\text { feedback }\end{array}$ & $\begin{array}{c}59 \text { teachers, } 186 \\
\text { students; Australia }\end{array}$ & Quantitative & $\begin{array}{l}\text { Teachers were more } \\
\text { positive }\end{array}$ \\
\hline 4 & $\begin{array}{c}\text { Vattøy and Smith } \\
\text { (2019) }\end{array}$ & $\begin{array}{l}\text { Students' perceptions } \\
\text { of teachers' feedback }\end{array}$ & $\begin{array}{l}1137 \text { students (13- } \\
16 \text { years); Norway }\end{array}$ & Quantitative & $\begin{array}{c}\text { Students perceived } \\
\text { teachers' feedback as more } \\
\text { useful. }\end{array}$ \\
\hline 5 & $\begin{array}{c}\text { Cutumisu and } \\
\text { Schwartz (2018) }\end{array}$ & $\begin{array}{l}\text { Impact of critical } \\
\text { feedback choice }\end{array}$ & $\begin{array}{l}106 \text { grade eight } \\
\text { students; California }\end{array}$ & $\begin{array}{c}\text { Quasi- } \\
\text { experimental }\end{array}$ & $\begin{array}{l}\text { Improved performance in } \\
\text { students }\end{array}$ \\
\hline 6 & $\begin{array}{l}\text { Pinger et al. } \\
\text { (2018a) }\end{array}$ & $\begin{array}{l}\text { The effectiveness of } \\
\text { feedback }\end{array}$ & $\begin{array}{l}17 \text { teachers and } 426 \\
\text { students; Germany }\end{array}$ & $\begin{array}{c}\text { Quasi- } \\
\text { experimental }\end{array}$ & $\begin{array}{l}\text { Improves math, interest, } \\
\text { and achievement }\end{array}$ \\
\hline 7 & $\begin{array}{l}\text { Kyaruzi et al. } \\
\text { (2019) }\end{array}$ & $\begin{array}{l}\text { Impact students' } \\
\text { perceptions }\end{array}$ & $\begin{array}{l}2767 \text { students; } \\
\text { Tanzania }\end{array}$ & $\begin{array}{l}\text { Mixed } \\
\text { Method }\end{array}$ & $\begin{array}{l}\text { Feedback predicted } \\
\text { performance }\end{array}$ \\
\hline
\end{tabular}

Source: Wafubwa

\section{Peer Assessment (PA) and Self-Assessment (SA)}

A total number of seven studies focused on PA whereas only one focused on SA (see Table 3). Two studies were surveys on students' perceptions of PA (Rotsaert et al. 2017) and teachers' perceptions of PA (Rotsaert, Panadero, and Schellens 2018). One study used a qualitative approach to study the implementation of PA in teaching the speaking skill (Musfirah 2019). The remaining five studies were experimental and sought to find out the effect of PA and SA in 
different learning conditions. For instance, Nikou and Economides (2016) looked at the impact of SA on student motivation and achievement in one high school in Europe. Rotsaert et al. (2018) examined how PA practice influences the quality of peer feedback; Tsivitanidou et al. (2017) examined reciprocal PA in modeling-based learning; Vanderhoven et al. (2015) investigated the effect of anonymity in PA; and Hsia, Huang, and Hwang (2016) examined the effects of a web-based PA approach. All the interventions in these experimental studies were postulated to have positive effects on the students' learning outcomes.

Peer assessment involves students providing feedback to their peers, and the feedback can either be verbal or written. According to Boud and Falchikov (2007), PA involves feedback on a product based on the standards of high quality for that product. Self-assessment is defined as a formative assessment process that enables students to reflect, evaluate, and judge the quality of their work and their learning (Andrade and Du 2007; Grantz and Gruber 2014). Only one study (Nikou and Economides 2016) in this review directly addressed the SA strategy. The majority of studies focused specifically on PA. It is unsurprising that only one study met the inclusion criterion for this review because the focus was on formative SA, which goes beyond students just assigning themselves a grade. Furthermore, the interest of the study was on how SA influenced the achievement, engagement, and motivation of the students. Most studies were excluded because they did not carry out SA under the framework of formative assessment, and instead, most were geared towards self-regulated learning (Panadero and Alonso-Tapia 2013).

The current trend on studies related to PA in secondary schools is quite encouraging since most studies are increasingly focusing on intervention programs as opposed to surveys. Previously, studies were focused more on universities. For instance, Van Gennip, Segers, and Tillema (2010) conducted a literature review on the effects of PA on achievement since 1990, and only one study out of fifteen studies focused on secondary education. The current study reviewed seven studies on PA, out of which more than half were experimental. Although survey studies revealed differing perceptions of teachers and students regarding PA, experimental studies presumed that PA could improve students' learning motivation and achievement. However, most of the studies $(75 \%)$ were carried out in Europe, and only 25 percent of studies were done in Asia. Evidently, from this analysis, PA works best in online environments and when students complete it anonymously. These findings are supported by previous studies (e.g., Tenório et al. 2016; Fu, Lin, and Hwang 2019). These studies showed that PA improves learning achievements and students' motivation.

Table 3: Peer Assessment (PA) and Self-Assessment Studies (SA) (N = 8)

\begin{tabular}{|c|c|c|c|c|c|}
\hline & Author & Description & Sample & Design & Main Findings \\
\hline 1 & $\begin{array}{l}\text { Rotsaert et al. } \\
\quad(2017) \\
\end{array}$ & $\begin{array}{c}\text { Perceptions of PA } \\
\text { by students }\end{array}$ & $\begin{array}{c}3680 \text { students; } \\
\text { Belgium }\end{array}$ & Quantitative & $\begin{array}{l}\text { Perceptions predicted by } \\
\text { trust } \\
\end{array}$ \\
\hline 2 & $\begin{array}{c}\text { Nikou, and } \\
\text { Economides (2016) }\end{array}$ & $\begin{array}{c}\text { SA on student } \\
\text { motivation and } \\
\text { achievement }\end{array}$ & $\begin{array}{l}66 \text { students; } \\
\text { Europe }\end{array}$ & $\begin{array}{l}\text { Quasi- } \\
\text { experimental }\end{array}$ & $\begin{array}{c}\text { Increased learning } \\
\text { achievement and motivation. }\end{array}$ \\
\hline 3 & Musfirah (2019) & $\begin{array}{l}\text { PA in teaching } \\
\text { speaking skill }\end{array}$ & $\begin{array}{l}1 \text { high school; } \\
\text { Indonesia }\end{array}$ & Qualitative & $\begin{array}{c}\text { Use of PA motivates } \\
\text { students }\end{array}$ \\
\hline 4 & $\begin{array}{l}\text { Rotsaert, Panadero, } \\
\text { and Schellens (2018) }\end{array}$ & $\begin{array}{c}\text { Use of PA among } \\
\text { teachers }\end{array}$ & $\begin{array}{l}225 \text { teachers; } \\
\text { Belgium }\end{array}$ & Quantitative & $\begin{array}{l}\text { PA predicts educational } \\
\text { beliefs }\end{array}$ \\
\hline 5 & $\begin{array}{l}\text { Rotsaert et al. } \\
\quad(2018)\end{array}$ & $\begin{array}{l}\text { Effects of PA } \\
\text { practice }\end{array}$ & $\begin{array}{l}36 \text { students; } \\
\text { Belgium }\end{array}$ & $\begin{array}{c}\text { Quasi- } \\
\text { experimental }\end{array}$ & PA improves peer feedback \\
\hline 6 & $\begin{array}{c}\text { Tsivitanidou et al. } \\
\text { (2017) }\end{array}$ & $\begin{array}{c}\text { Reciprocal PA as a } \\
\text { learning tool }\end{array}$ & $\begin{array}{l}22 \text { students; } \\
\text { Switzerland }\end{array}$ & $\begin{array}{c}\text { Quasi- } \\
\text { experimental }\end{array}$ & Facilitates students' learning \\
\hline 7 & $\begin{array}{l}\text { Vanderhovn et al. } \\
\qquad(2015)\end{array}$ & $\begin{array}{l}\text { Effect of anonymity } \\
\text { in PA }\end{array}$ & $\begin{array}{c}2 \text { teachers and } 69 \\
\text { students; } \\
\text { Belgium } \\
\end{array}$ & $\begin{array}{l}\text { Quasi- } \\
\text { experimental }\end{array}$ & $\begin{array}{l}\text { Pupils felt more positive } \\
\text { towards anonymity in PA }\end{array}$ \\
\hline 8 & $\begin{array}{l}\text { Hsia, Huang, and } \\
\text { Hwang (2016) }\end{array}$ & $\begin{array}{c}\text { Effects of web-based } \\
\text { PA }\end{array}$ & $\begin{array}{l}163 \text { junior high } \\
\text { students; Taiwan }\end{array}$ & $\begin{array}{c}\text { Quasi- } \\
\text { experimental }\end{array}$ & $\begin{array}{c}\text { Improved learning } \\
\text { performance and motivation }\end{array}$ \\
\hline
\end{tabular}




\section{Five Strategies Combined}

After analyzing studies with specific strategies as discussed above, studies that involved a combination of formative assessment strategies, or at least examined the effect of formative assessment in general, were analyzed together as shown in Table 4. In total, twenty-one studies focused on a combination of strategies; five studies investigated either teachers' perceptions, students' perceptions, or both teachers' and students' perceptions (Burner 2016; Dobish, Griffiths, and Meyer 2017; Saito and Inoi 2017; Ozan and Kincal 2018; Kippers et al. 2018; Rakoczy et al. 2019; and Johnson, Sondergeld, and Walton 2019).

Five studies were experimental. Two quasi-experimental studies (Vogelzang and Admiraal 2017; Pinger et al. 2018b) investigated the effect of formative assessment on chemistry achievement and instructional quality, respectively. Two longitudinal experimental studies (Wylie and Lyon 2015; Furtak et al. 2016) determined the quality of formative assessment implementation after teachers' professional development, whereas Rakoczy et al. (2019) used a cluster randomized field trial with pre-tests and post-tests to find out the effect of formative assessment intervention on students' achievement and interest.

One study (Yin and Buck 2019) used collaborative action research to negotiate the conception of formative assessment by the teachers. Two qualitative studies (Van der Nest, Long, and Engelbrecht 2018; Beesley et al. 2018) focused on teachers' professional development while three studies (Brink and Bartz 2017; Cisterna and Gotwals 2018; Lyon, Oláh, and Wylie 2019) focused on the implementation of formative assessment. Other non-experimental but quantitative studies also focused on the implementation and use of formative assessment (Bulunuz et al. 2015; Saito and Inoi 2017; Choi, Kim, and Pak 2018; Xiao and Yang 2019).

Table 4: Studies on a Combination of Formative Assessment (FA) Aspects ( $\mathrm{N}=21)$

\begin{tabular}{|c|c|c|c|c|c|}
\hline & Study & Description & Sample & Design & Main Findings \\
\hline 1 & $\begin{array}{l}\text { Dobish, Griffiths, } \\
\text { and Meyer (2017) }\end{array}$ & $\begin{array}{l}\text { Teachers' } \\
\text { perceptions }\end{array}$ & 305 teachers; USA & $\begin{array}{l}\text { Mixed } \\
\text { Method }\end{array}$ & $\begin{array}{l}\text { Improved teachers' practice } \\
\text { and students' learning }\end{array}$ \\
\hline 2 & $\begin{array}{c}\text { Bulunuz et al. } \\
\text { (2015) }\end{array}$ & Use of FA probes & $\begin{array}{l}61 \text { students; } \\
\text { Turkey }\end{array}$ & Quantitative & $\begin{array}{l}\text { Improved students' } \\
\text { performance. }\end{array}$ \\
\hline 3 & Choi et al. (2018) & $\begin{array}{l}\text { Automatic Item } \\
\text { Generation (AIG) }\end{array}$ & $\begin{array}{l}57 \text { students and } \\
\text { teachers; Korea }\end{array}$ & $\begin{array}{l}\text { Mixed- } \\
\text { Method }\end{array}$ & $\begin{array}{l}\text { AIG can be utilized for } \\
\text { students and teachers }\end{array}$ \\
\hline 4 & Burner (2016) & $\begin{array}{l}\text { FA in English as a } \\
\text { foreign language }\end{array}$ & $\begin{array}{c}4 \text { teachers } 100 \\
\text { students; Norway }\end{array}$ & Quantitative & $\begin{array}{l}\text { Differing teachers' and } \\
\text { students' perceptions }\end{array}$ \\
\hline 5 & $\begin{array}{c}\text { Pinger et al. } \\
(2018 b)\end{array}$ & $\begin{array}{l}\text { Effects of FA on } \\
\text { instruction }\end{array}$ & $\begin{array}{c}35 \text { teachers, } 859 \\
\text { students; Germany }\end{array}$ & Experimental & $\begin{array}{l}\text { Improves achievement and } \\
\text { safe on instructional time. }\end{array}$ \\
\hline 6 & $\begin{array}{c}\text { Ozan and Kincal } \\
\text { (2018) }\end{array}$ & $\begin{array}{l}\text { Effects of FA on } \\
\text { achievement }\end{array}$ & $\begin{array}{l}45 \text { students; } \\
\text { Turkey }\end{array}$ & $\begin{array}{l}\text { Mixed } \\
\text { Method }\end{array}$ & $\begin{array}{l}\text { Increased achievement and } \\
\text { better attitudes }\end{array}$ \\
\hline 7 & $\begin{array}{l}\text { Vogelzang and } \\
\text { Admiraal (2017) }\end{array}$ & $\begin{array}{l}\text { Effects of FA on } \\
\text { achievement }\end{array}$ & $\begin{array}{l}69 \text { students; } \\
\text { Netherlands }\end{array}$ & Experimental & $\begin{array}{c}\text { Positive effect on students' } \\
\text { achievement }\end{array}$ \\
\hline 8 & $\begin{array}{l}\text { Kippers et al. } \\
\quad(2018)\end{array}$ & $\begin{array}{c}\text { Teachers' view on } \\
\text { AfL }\end{array}$ & $\begin{array}{l}479 \text { teachers; } \\
\text { Netherlands }\end{array}$ & $\begin{array}{l}\text { Mixed } \\
\text { Method }\end{array}$ & $\begin{array}{l}\text { AfL lacking in teacher } \\
\text { practice }\end{array}$ \\
\hline 9 & Furtak et al. (2016) & $\begin{array}{l}\text { Teachers' FA } \\
\text { abilities }\end{array}$ & 9 teachers; USA & Experimental & $\begin{array}{l}\text { Increase in teachers use FA } \\
\text { strategies }\end{array}$ \\
\hline 10 & $\begin{array}{c}\text { Cisterna and } \\
\text { Gotwals 2018). }\end{array}$ & $\begin{array}{c}\text { Teachers' } \\
\text { enactment of FA }\end{array}$ & 4 teachers; USA & Qualitative & $\begin{array}{l}\text { Teachers struggled with } \\
\text { integrating FA }\end{array}$ \\
\hline 11 & $\begin{array}{l}\text { Yin and Buck } \\
\quad(2019)\end{array}$ & $\begin{array}{l}\text { Collaborative } \\
\text { action research }\end{array}$ & $\begin{array}{l}2 \text { chemistry } \\
\text { teachers; USA }\end{array}$ & Experimental & $\begin{array}{l}\text { Teachers need support to } \\
\text { use action research in FA }\end{array}$ \\
\hline 12 & $\begin{array}{l}\text { Lyon, Oláh, and } \\
\text { Wylie (2019) }\end{array}$ & $\begin{array}{l}\text { An integrated } \\
\text { approach, FA }\end{array}$ & 6 teachers; USA & Qualitative & $\begin{array}{l}\text { FA determines } \\
\text { Implementation }\end{array}$ \\
\hline
\end{tabular}




\begin{tabular}{|c|c|c|c|c|c|}
\hline & Study & Description & Sample & Design & Main Findings \\
\hline 13 & $\begin{array}{l}\text { Wylie and Lyon } \\
\text { (2015) }\end{array}$ & $\begin{array}{l}\text { Breadth and } \\
\text { quality of FA }\end{array}$ & 202 teachers; USA & Experimental & $\begin{array}{c}\text { Significant improvements } \\
\text { in FA }\end{array}$ \\
\hline 14 & Xiao (2017) & Formative tests & 3 classes; China & Qualitative & $\begin{array}{c}\text { Tests used to a certain } \\
\text { degree }\end{array}$ \\
\hline 15 & $\begin{array}{c}\text { Xiao and Yang } \\
(2019)\end{array}$ & $\begin{array}{l}\text { FA and students' } \\
\text { self-regulation }\end{array}$ & 2 teachers; China & Qualitative & $\begin{array}{c}\text { Enhance students' self- } \\
\text { regulation }\end{array}$ \\
\hline 16 & $\begin{array}{l}\text { Saito and Inoi } \\
\text { (2017) }\end{array}$ & $\begin{array}{l}\text { FA, English } \\
\text { Teachers }\end{array}$ & $\begin{array}{l}727 \text { teachers; } \\
\text { Japan }\end{array}$ & Quantitative & Varying degrees of FA use \\
\hline 17 & $\begin{array}{l}\text { Brink and Bartz } \\
\text { (2017) }\end{array}$ & $\begin{array}{l}\text { Perceptions of FA } \\
\text { by teachers }\end{array}$ & 3 teachers; USA & $\begin{array}{l}\text { Mixed } \\
\text { Method }\end{array}$ & $\begin{array}{l}\text { Positive impact on the use } \\
\text { of FA }\end{array}$ \\
\hline 18 & $\begin{array}{l}\text { Van der Nest, Long, } \\
\text { and Engelbrecht } \\
\text { (2018) }\end{array}$ & $\begin{array}{l}\text { Impact of FA } \\
\text { activities on }\end{array}$ & $\begin{array}{c}\text { Math teachers; } \mathrm{S} \text {. } \\
\text { Africa }\end{array}$ & Qualitative & $\begin{array}{l}\text { Need for multiple } \\
\text { dimensions in math }\end{array}$ \\
\hline 19 & $\begin{array}{c}\text { Beesley et al. } \\
(2018)\end{array}$ & $\begin{array}{c}\text { FA professional } \\
\text { development }\end{array}$ & $\begin{array}{l}7 \text { schools, } 47 \\
\text { teachers; USA }\end{array}$ & Qualitative & $\begin{array}{c}\text { Improved teachers' practice } \\
\text { of FA. }\end{array}$ \\
\hline 20 & $\begin{array}{l}\text { Rakoczy et al. } \\
(2019)\end{array}$ & $\begin{array}{c}\text { FA, interest, and } \\
\text { achievement }\end{array}$ & $\begin{array}{l}26 \text { teachers; } \\
\text { Germany }\end{array}$ & Experimental & $\begin{array}{c}\text { The indirect effect on } \\
\text { interest }\end{array}$ \\
\hline 21 & $\begin{array}{c}\text { Johnson, } \\
\text { Sondergeld, and } \\
\text { Walton (2019) }\end{array}$ & $\begin{array}{l}\text { FA in public } \\
\text { school districts }\end{array}$ & $\begin{array}{l}\text { 1,097 teachers; } \\
\text { USA }\end{array}$ & $\begin{array}{l}\text { Mixed } \\
\text { Method }\end{array}$ & Less use of FA strategies \\
\hline
\end{tabular}

Although this study aimed to find out how specific strategies of formative assessment have been applied in research, twenty-one studies did not focus on a single strategy but focused on formative assessment as a whole. The analysis of these studies has revealed that the impact of formative assessment is more pronounced when the implementation is done within the context of teachers' professional development (e.g., Wylie and Lyon 2015; Brink and Bartz 2017; Dobish, Griffiths, and Meyer 2017; Beesley et al. 2018). Generally, formative assessment is seen to have a positive effect on learning outcomes when well implemented. One outstanding fact is that most studies focused on teachers' and students' attitudes. However, the sample sizes in the experimental studies were small, limiting the generalization of results. A summary of all the studies based on different strategies is presented in Table 5.

Table 5: Summary of Studies on the Five Aspects of Formative Assessment

\begin{tabular}{|c|c|c|c|c|c|}
\hline Aspect & $n$ & $\%$ & Design & Purpose & Results \\
\hline $\begin{array}{l}\text { Learning Intention } \\
\text { (LI) and Success } \\
\text { criteria (SC) }\end{array}$ & 2 & 5.4 & $\begin{array}{l}\text { Qualitative and } \\
\text { quantitative }\end{array}$ & $\begin{array}{l}\text { Teachers and } \\
\text { students' } \\
\text { perceptions }\end{array}$ & $\begin{array}{c}\text { Difficulties in } \\
\text { implementing the } \\
\text { strategies by teachers }\end{array}$ \\
\hline $\begin{array}{l}\text { Appropriate } \\
\text { feedback }\end{array}$ & 7 & 18.9 & $\begin{array}{c}\text { Qualitative, } \\
\text { quantitative, and } \\
\text { experimental }\end{array}$ & $\begin{array}{l}\text { Effect of } \\
\text { feedback use }\end{array}$ & $\begin{array}{c}\text { Increase in motivation and } \\
\text { achievement }\end{array}$ \\
\hline $\begin{array}{l}\text { Peer assessment } \\
\text { (PA) and Self- } \\
\text { Assessment (SA) }\end{array}$ & 8 & 18.9 & $\begin{array}{c}\text { Qualitative, } \\
\text { quantitative, and } \\
\text { experimental }\end{array}$ & $\begin{array}{l}\text { Teachers and } \\
\text { students' } \\
\text { perceptions }\end{array}$ & $\begin{array}{l}\text { Increased motivation, } \\
\text { differing perceptions of } \\
\text { teachers and students }\end{array}$ \\
\hline $\begin{array}{l}\text { All five strategies } \\
\text { (combined) }\end{array}$ & 21 & 56.8 & $\begin{array}{c}\text { Qualitative, } \\
\text { quantitative, and } \\
\text { experimental }\end{array}$ & $\begin{array}{l}\text { Teachers and } \\
\text { students' } \\
\text { perceptions }\end{array}$ & $\begin{array}{c}\text { Enhances motivation, } \\
\text { engagement, and } \\
\text { achievement }\end{array}$ \\
\hline
\end{tabular}

Source: Wafubwa

\section{Conclusion}

The present study focused on peer-reviewed empirical studies that have been done within a period of five years (2015-2019). The review was limited to international peer-reviewed studies done in English and within secondary school education settings. The term secondary school has been used 
to generally include studies also done in middle schools and high schools. The aim of carrying out this review was to find out the extent to which formative assessment aspects have been addressed in studies. The review was carried out systematically, and analysis was done thematically based on the strategies of formative assessment described by Black and Wiliam (2009). An overview of the analysis revealed that most of the studies were done in Europe (seventeen studies), followed by the USA (eleven studies), Asia (six studies), Africa (three studies), and Australia (one study).

The analysis revealed that feedback and PA strategies have significantly been studied in the past five years by the education researchers, especially between 2018 and 2019. Only two studies addressed LI and SC, making it a potential strategy for future inquiry. Although there is evidence from the past studies that SA can improve students' performance (Brown and Harris 2013), only one study in this review met the criteria for inclusion in the review. The focus of most studies on SA has been its relationship with students' self-regulation (Panadero, Jonsson, and Botella 2017). There is a need for more clarity in the concept of SA, especially in the context of formative assessment. Seemingly, most studies have used the term SA in studies without a solid theoretical framework. These sentiments are also echoed in the study by Panadero, Brown, and Strijbos (2016), who argued that there are different conceptions of SA components, yet they have been treated uniformly in educational studies. Self-assessment in this current study was conceptualized as an instructional strategy in which students get involved with their work (Panadero and Alonso-Tapia 2013) and how the strategy will impact students' achievement, engagement, and motivation.

There was no specific study focusing on the use of classroom discussions and questions, which are also the main strategies of formative assessment. Though all studies were quantitative, most used questionnaires to get the perceptions of teachers and students regarding formative assessment. There is a need for more focus on experimental research so that more realistic conclusions regarding the role of formative assessment can be obtained. In the current review, only eleven studies out of thirty-eight were experimental. The results of these experimental studies pointed out a varying degree of the use of formative assessment strategies by teachers after undergoing professional development and a positive educational outcome for students in the treatment groups. There is a need for more research to focus on intervention studies. Studies have suggested that the key elements of formative assessment can increase students' learning outcomes (motivation, engagement, and achievement) if well implemented. An important observation in this review is an increase in the use of mixed methods, unlike before where studies on formative assessment were characterized as flawed due to methodological issues (Dunn and Mulvenon 2009; Kingston and Nash 2011).

\section{Limitations}

The analysis in this review focused on articles that have been published in internationally recognized peer-reviewed journals between 2015 and 2019. There is a possibility that some unpublished studies and those published in journals with a limited audience may have been left out. The second limitation regards the inclusion of only articles published in the English language. Other relevant articles that were not published in English may have been left out. The results of this review should, therefore, be interpreted cautiously. Third, the analysis only included studies within secondary education. The effects of formative assessment in these studies cannot be generalized to other educational levels like elementary schools or universities.

\section{Theoretical Implications and Recommendations for Further Research}

This study was carried out under the theoretical framework of formative assessment as defined by Black and Wiliam (2009). For the future advancement of this theory, all the five key strategies defining the formative assessment process must be put into perspective. From the 
analysis of thirty-eight selected studies, it was noted that some strategies have not been tested empirically. A case in point is the use of classroom discussions that help in eliciting evidence of student understanding. Other strategies that have been least used are LI, SC, and the use of SA as an instruction process. There is a need for future researchers to utilize these strategies for the formative assessment theory to remain meaningful. Another important finding was on where these studies have been implemented. The analysis revealed that most studies have been carried out in Europe and the USA with a few studies in Asia, but there were only three in Africa and one in Australia. This implies that formative assessment has not been well embraced globally, and therefore, researchers in the affected continents can take up the challenge and spearhead the implementation of formative assessment.

\section{Practical Implications}

The findings of this review have shown that the process of formative assessment can improve the learning outcomes, especially when teachers go through professional development. Schools should embrace the in-service training of teachers on how to effectively implement formative assessment strategies. Teachers should also be motivated, so they can willingly apply formative assessment strategies for better learning outcomes.

\section{REFERENCES}

Andrade, Heidi, and Ying Du. 2007. "Student Responses to Criteria-Referenced SelfAssessment." Assessment and Evaluation in Higher Education 32 (2): 159-181. https://doi.org/10.1080/02602930600801928.

Beesley, Andrea D., Tedra F. Clark, Kathleen Dempsey, and Anne Tweed. 2018. "Enhancing Formative Assessment Practice and Encouraging Middle School Mathematics Engagement and Persistence." School Science and Mathematics 118 (1-2): 4-16. https://doi.org/10.1111/ssm.12255.

Bennett, Randy Elliot. 2011. "Formative Assessment: A Critical Review." Assessment in Education: Principles, Policy and Practice 18 (1): 5-25. https://doi.org/10.1080/0969594X.2010.513678.

Black, Paul, and Dylan Wiliam. 1998. "Assessment and Classroom Learning." Assessment in Education: Principles, Policy and Practice 5 (1): 7-74. https://doi.org/10.1080/0969595980050102.

2009. "Developing the Theory of Formative Assessment." Educational Assessment, Evaluation, and Accountability 21 (1). https://doi.org/10.1007/s11092-008-9068-5.

Briggs, Derek C., Maria Araceli Ruiz-Primo, Erin Furtak, Lorrie Shepard, and Yue Yin. 2012. "Meta-Analytic Methodology and Inferences about the Efficacy of Formative Assessment." Educational Measurement: Issues and Practice 31 (4): 13-17. https://doi.org/10.1111/j.1745-3992.2012.00251.x.

Brink, Melanie, and David E. Bartz. 2017. "Effective Use of Formative Assessment by High School Teachers." Practical Assessment, Research, and Evaluation 22 (1). https://doi.org/10.7275/p86s-zc41.

Brookhart, Susan M. 2011. "Educational Assessment Knowledge and Skills for Teachers." Educational Measurement: Issues and Practice 30 (1): 3-12. https://doi.org/10.1111/j.1745-3992.2010.00195.x.

Brown, Gavin, and Lois R. Harris. 2013. "Student Self-Assessment." In SAGE Handbook of Research on Classroom Assessment, edited by James H. McMillan, 367-389. New York: SAGE Publications.

Boud, David, and Nancy Falchikov, eds. 2007. Rethinking Assessment in Higher Education: Learning for the Longer Term. New York: Routledge. 
Bulunuz, Nermin, Omer Tavsanli, Mizrap Bulunuz, and Funda Karagoz. 2015. "Achievement Levels of Middle School Students in the Standardized Science and Technology Exam and Formative Assessment Probes: A Comparative Study." Journal of Education in Science, Environment and Health 2 (1): 33-50. https://dergipark.org.tr/en/pub/jeseh/issue/18650/196800.

Burner, Tony. 2016. "Formative Assessment of Writing in English as a Foreign Language." Scandinavian Journal of Educational Research 60 (6): 626-648. https://doi.org/10.1080/00313831.2015.1066430.

Cauley, Kathleen M., and James H. McMillan. 2010. "Formative Assessment Techniques to Support Student Motivation and Achievement." Clearinghouse: A Journal of Educational Strategies, Issues, and Ideas 83 (1): 1-6. https://doi.org/10.1080/00098650903267784.

Choi, Jaehwa, HeeKyoung Kim, and Seohong Pak. 2018. "Evaluation of Automatic Item Generation Utilities in Formative Assessment Application for Korean High School Students.” Journal of Educational Issues 4 (1): 68-89. https://doi.org/10.5296/jei.v4i1.12630.

Cisterna, Dante, and Amelia Wenk Gotwals. 2018. "Enactment of Ongoing Formative Assessment: Challenges and Opportunities for Professional Development and Practice." Journal of Science Teacher Education 29 (3): 200-222. https://doi.org/10.1080/1046560X.2018.1432227.

Crichton, Hazel, and Ann McDaid. 2016. "Learning Intentions and Success Criteria: Learners 'and Teachers' Views." Curriculum Journal 27 (2): 190-203. https://doi.org/10.1080/09585176.2015.1103278.

Cutumisu, Maria, and Daniel L. Schwartz. 2018. "The Impact of Critical Feedback Choice on Students' Revision, Performance, Learning, and Memory." Computers in Human Behavior 78:351-367. https://doi.org/10.1016/j.chb.2017.06.029.

Dann, Ruth. 2014. "Assessment as Learning: Blurring the Boundaries of Assessment and Learning for Theory, Policy, and Practice." Assessment in Education: Principles, Policy and Practice 21 (2): 149-166. https://doi.org/10.1080/0969594X.2014.898128.

Dobish, Melisa, Jacqueline Griffiths, and Richard Meyer. 2017. "Improving Teaching and Learning Using the Keeping Learning on Track Professional Development Program and Strategies." Journal for Leadership and Instruction 16 (1): 22-26. https://files.eric.ed.gov/fulltext/EJ1159870.pdf.

Dunn, Karee E., and Sean W. Mulvenon. 2009. "A Critical Review of Research on Formative Assessments: The Limited Scientific Evidence of the Impact of Formative Assessments in Education." Practical Assessment, Research, and Evaluation 14 (1). https://doi.org/10.7275/jg4h-rb87.

Fu, Qing-Ke, Chi-Jen Lin, and Gwo-Jen Hwang. 2019. "Research Trends and Applications of Technology-Supported Peer Assessment: A Review of Selected Journal Publications from 2007 to 2016." Journal of Computers in Education 6 (2): 191-213. https://link.springer.com/content/pdf/10.1007/s40692-019-00131-X.pdf.

Furtak, Erin Marie, Katharina Kiemer, Ruhan Kizil Circi, Rebecca Swanson, Vanessa de León, Deb Morrison, and Sara C. Heredia. 2016. "Teachers' Formative Assessment Abilities and Their Relationship to Student Learning: Findings from a Four-Year Intervention Study." Instructional Science 44 (3): 267-291. https://doi.org/10.1007/s11251-016-9371-3.

Grantz, Regina E., and Robert Gruber. 2014. “'How Well Did I Learn What I Learned?' The Art of Self-Assessment." Journal of the Academy of Business Education 15:23-40. https://search.proquest.com/openview/5e500ebade1485cec07063d4afd8d608/1?cbl=20 40119\&pq-origsite $=$ gscholar.

Hattie, John. 2008. Visible Learning: A Synthesis of Over 800 Meta-Analyses Relating to Achievement. New York: Routledge. https://apprendre.auf.org/. 
Hattie, John, and Helen Timperley. 2007. "The Power of Feedback." Review of Educational Research 77 (1): 88-118. https://doi.org/10.3102/003465430298487.

Havis, Leanne. 2016. "The Impact of Feedback as a Formative Assessment on Student Performance." International Journal of Teaching and Learning in Higher Education 28 (2): 168-175. https://www.researchgate.net/publication/331742549.

Hendriks, Maria A. M., Johannes W. Luyten, Jaap Scheerens, and P. J. C. Sleegers. 2014. "Effects of Evaluation and Assessment on Student Achievement: A Review and Meta-Analysis." In The Influence of School Size, Leadership, Evaluation, and Time on Student Outcomes, edited by M. Hendriks, 127-174. Enschede, NL: University of Twente.

Hsia, Lu-Ho, Iwen Huang, and Gwo-Jen Hwang. 2016. "A Web-Based Peer-Assessment Approach to Improving Junior High School Students’ Performance, Self-Efficacy, and Motivation in Performing Arts Courses." British Journal of Educational Technology 47 (4): 618-632. https://doi.org/10.1111/bjet.12248.

Johnson, Carla C., Toni A. Sondergeld, and Janet B. Walton. 2019. "A Study of the Implementation of Formative Assessment in Three Large Urban Districts." American Educational Research Journal 56 (6): 2408-2438. https://doi.org/10.3102/0002831219842347.

Jónsson, Ívar Rafn, Kari Smith, and Guðrún Geirsdóttir. 2018. "Shared Language of Feedback and Assessment. Perception of Teachers and Students in Three Icelandic Secondary Schools." Studies in Educational Evaluation 56:52-58. https://doi.org/10.1016/j.stueduc.2017.11.003.

Kingston, Neal, and Brooke Nash. 2011. "Formative Assessment: A Meta-Analysis and a Call for Research." Educational Measurement: Issues and Practice 30 (4): 28-37. https://doi.org/10.1111/j.1745-3992.2011.00220.x.

Kippers, Wilma B., Christel H. D. Wolterinck, Kim Schildkamp, Cindy L. Poortman, and Adrie J. Visscher. 2018. "Teachers' Views on the Use of Assessment for Learning and DataBased Decision Making in Classroom Practice." Teaching and Teacher Education 75: 199-213. https://doi.org/10.1016/j.tate.2018.06.015.

Krijgsman, Christa, Tim Mainhard, Jan van Tartwijk, Lars Borghouts, Maarten Vansteenkiste, Nathalie Aelterman, and Leen Haerens. 2019. "Where to Go and How to Get There: Goal Clarification, Process Feedback and Students' Need Satisfaction and Frustration from Lesson to Lesson." Learning and Instruction 61: 1-11. https://doi.org/10.1016/j.learninstruc.2018.12.005.

Kyaruzi, Florence, Jan-Willem Strijbos, Stefan Ufer, and Gavin T. L. Brown. 2018. "Teacher Afl Perceptions and Feedback Practices in Mathematics Education among Secondary Schools in Tanzania." Studies in Educational Evaluation 59: 1-9. https://doi.org/10.1016/j.stueduc.2018.01.004.

2019. "Students' Formative Assessment Perceptions, Feedback Use, and Mathematics Performance in Secondary Schools in Tanzania." Assessment in Education: Principles, Policy \& Practice 26 (3): 278-302. https://doi.org/10.1080/0969594X.2019.1593103.

Leach, Linda. 2012. "Optional Self-Assessment: Some Tensions and Dilemmas." Assessment and Evaluation in Higher Education $37 \quad$ (2): 137-147. https://doi.org/10.1080/02602938.2010.515013.

Lyon, Christine J., Leslie Nabors Oláh, and E. Caroline Wylie. 2019. "Working toward Integrated Practice: Understanding the Interaction among Formative Assessment Strategies." Journal of Educational Research 112 (3): 301-314. https://doi.org/10.1080/00220671.2018.1514359.

Moss, Connie M., Susan M. Brookhart, and Beverly A. Long. 2011. "Knowing Your Learning Target." Educational Leadership 68 (6): 66-69. http://www.ascd.org/publications/ educational-leadership/mar11/vol68/num06/Knowing-Your-Learning-Target.aspx.

Musfirah, Yusna. 2019. "The Use of Peer Assessment in Speaking Skill.” English Education Journal $10 \quad$ (1): 67-79. https://pdfs.semanticscholar.org/602b/ 278cdef9f97934baaa10316c48e18fb76954.pdf. 
Nicol, David J., and Debra Macfarlane-Dick. 2004. "Rethinking Formative Assessment in HE: A Theoretical Model and Seven Principles of Good Feedback Practice." https://www1.villanova.edu/content/dam/villanova/vital/vitalinks/7principlesofgoodfee dback04.pdf.

Nikou, Stavros A., and Anastasios A. Economides. 2016. "The Impact of Paper-Based, Computer-Based, and Mobile-Based Self-Assessment on Students' Science Motivation and Achievement." Computers in Human Behavior 55:1241-1248. https://doi.org/10.1016/j.chb.2015.09.025.

Ozan, Ceyhun, and Remzi Y. Kincal. 2018. "The Effects of Formative Assessment on Academic Achievement, Attitudes toward the Lesson, and Self-Regulation Skills." Educational Sciences: Theory and Practice 18 (1): 85-118. https://doi.org/10.12738/estp.2018.1.0216.

Panadero, Ernesto, and Jesús Alonso-Tapia. 2013. "Self-Assessment: Theoretical and Practical Connotations, When it Happens, How is it Acquired and What to do to Develop it in Our Students." Electronic Journal of Research in Educational Psychology 11 (30): 551-576. https://doi.org/10.14204/ejrep.30.12200.

Panadero, Ernesto, Gavin T. L. Brown, and Jan-Willem Strijbos. 2016. "The Future of Student SelfAssessment: A Review of Known Unknowns and Potential Directions." Educational Psychology Review 28 (4): 803-830. https://doi.org/10.1007/s10648-015-9350-2.

Panadero, Ernesto, Anders Jonsson, and Juan Botella. 2017. "Effects of Self-Assessment on Self-Regulated Learning and Self-Efficacy: Four Meta-Analyses." Educational Research Review 22: 74-98. https://doi.org/10.1016/j.edurev.2017.08.004.

Pinger, Petra, Katrin Rakoczy, Michael Besser, and Eckhard Klieme. 2018a. "Implementation of Formative Assessment-Effects of Quality of Program Delivery on Students' Mathematics Achievement and Interest." Assessment in Education: Principles, Policy and Practice 25 (2): 160-182. https://doi.org/10.1080/0969594X.2016.1170665.

2018b. "Interplay of Formative Assessment and Instructional Quality-Interactive Effects on Students' Mathematics Achievement." Learning Environments Research 21:61-79. https://doi.org/10.1007/s10984-017-9240-2.

Popay, Jennie, Helen Roberts, Amanda Sowden, Mark Petticrew, Lisa Arai, Mark Rodgers, Nicky Britten, Katrina Roen, and Steven Duffy. 2006. "Guidance on the Conduct of Narrative Synthesis in Systematic Reviews." ESRC Methods Programme Version. https://doi.org/10.13140/2.1.1018.4643.

Rakoczy, Katrin, Petra Pinger, Jan Hochweber, Eckhard Klieme, Birgit Schütze, and Michael Besser. 2019. "Formative Assessment in Mathematics: Mediated by Feedback's Perceived Usefulness and Students' Self-Efficacy." Learning and Instruction 60: 154-165. https://doi.org/10.1016/j.learninstruc.2018.01.004.

Rotsaert, Tijs, Ernesto Panadero, Eduardo Estrada, and Tammy Schellens. 2017. "How do Students Perceive the Educational Value of Peer Assessment in Relation to its Social Nature? A Survey Study in Flanders." Studies in Educational Evaluation 53:29-40. https://doi.org/10.1016/j.stueduc.2017.02.003.

Rotsaert, Tijs, Ernesto Panadero, and Tammy Schellens. 2018. "Peer Assessment Use, Its Social Nature Challenges, and Perceived Educational Value: A Teachers' Survey Study." Studies in Educational Evaluation 59:124-132. https://doi.org/10.1016/j.stueduc.2018.07.001.

Rotsaert, Tijs, Ernesto Panadero, Tammy Schellens, and Annelis Raes. 2018. "Now You Know What You're Doing Right and Wrong!' Peer Feedback Quality in Synchronous Peer Assessment in Secondary Education." European Journal of Psychology of Education 33 (2): 255-275. https://doi.org/10.1007/s10212-017-0329-x.

Saito, Hidetoshi, and Shin'ichi Inoi. 2017. "Junior and Senior High School EFL Teachers' Use of Formative Assessment: A Mixed-Methods Study." Language Assessment Quarterly 14 (3): 213-233. https://doi.org/10.1080/15434303.2017.1351975. 
Shute, Valerie J. 2008. "Focus on Formative Feedback." Review of Educational Research 78 (1): 153-189. https://doi.org/10.3102/0034654307313795.

Spiller, Dorothy. 2012. Assessment Matters: Self-Assessment and Peer Assessment. Hamilton, New Zealand: University of Waikato.

Swaffield, Sue. 2011. "Getting to the Heart of Authentic Assessment for Learning." Assessment in Education: Principles, Policy and Practice 18 (4): 433-449. https://doi.org/10.1080/0969594X.2011.582838.

Taras, Maddalena. 2010. "Student Self-Assessment: Processes and Consequences." Teaching in Higher Education 15 (2): 199-209. https://doi.org/10.1080/13562511003620027.

Tenório, Thyago, Ig Ibert Bittencourt, Seiji Isotani, and Alan Pedro Silva. 2016. "Does Peer Assessment in On-Line Learning Environments Work? A Systematic Review of the Literature." Computers in Human Behavior 64:94-107. https://doi.org/10.1016/j.chb.2016.06.020.

Torrance, Harry. 2012. "Formative Assessment at the Crossroads: Conformative, Deformative, and Transformative Assessment." Oxford Review of Education 38 (3): 323-342. https://doi.org/10.1080/03054985.2012.689693.

Tsivitanidou, Olia E., Costas P. Constantinou, Peter Labudde, Silke Rönnebeck, and Mathias Ropohl. 2017. "Reciprocal Peer Assessment as a Learning Tool for Secondary School Students in Modeling-Based Learning." European Journal of Psychology of Education 33 (1): 51-73. https://doi.org/10.1007/s10212-017-0341-1.

Vanderhoven, Ellen, Annelies Raes, Hannelore Montrieux, Tijs Rotsaert, and Tammy Schellens. 2015. "What if Pupils Can Assess Their Peers Anonymously? A QuasiExperimental Study." Computers and Education 81: 123-132. https://doi.org/10.1016/j.compedu.2014.10.001.

Van der Nest, Adri, Caroline Long, and Johann Engelbrecht. 2018. "The Impact of Formative Assessment Activities on the Development of Teacher Agency in Mathematics Teachers." South African Journal of Education 38 (1). https://doi.org/10.15700/saje.v38n1a1382.

Van der Kleij, Fabienne M., Remco C. W. Feskens, and Theo J. H. M. Eggen. 2015. "Effects of Feedback in a Computer-Based Learning Environment on Students' Learning Outcomes: A Meta-Analysis." Review of Educational Research 85 (4): 475-511. https://doi.org/10.3102/0034654314564881.

Van der Kleij, Fabienne M. 2019. "Comparison of Teacher and Student Perceptions of Formative Assessment Feedback Practices and Association with Individual Student Characteristics." Teaching and Teacher Education 85: 175-189. https://doi.org/10.1016/j.tate.2019.06.010.

Van Gennip, Nanine A. E., Mien S. R. Segers, and Harm H. Tillema. 2010. "Peer Assessment as a Collaborative Learning Activity: The Role of Interpersonal Variables and Conceptions." Learning and Instruction $20 \quad$ (4): 280-290. https://doi.org/10.1016/j.learninstruc.2009.08.010.

Vattøy, Kim-Daniel, and Kari Smith. 2019. "Students 'Perceptions of Teachers' Feedback Practice in Teaching English as a Foreign Language." Teaching and Teacher Education 85:260-268. https://doi.org/10.1016/j.tate.2019.06.024.

Veenman, Marcel V. J. 2011. "Alternative Assessment of Strategy Use with Self-Report: A Discussion." Metacognition Learning $6 \quad$ (2): $205-211$. https://doi.org/10.1007/s11409-011-9080-x.

Vogelzang, Johannes, and Wilfried F. Admiraal. 2017. "Classroom Action Research on Formative Assessment in a Context-Based Chemistry Course." Educational Action Research 25 (1): 155-166. https://doi.org/10.1080/09650792.2016.1177564.

Wiliam, Dylan. 2011. Embedded Formative Assessment. Bloomington, IN: Solution Tree Press.

Wylie, E. Caroline, and Christine J. Lyon. 2015. "The Fidelity of Formative Assessment Implementation: Issues of Breadth and Quality." Assessment in Education: Principles, Policy and Practice 22 (1): 140-160. https://doi.org/10.1080/0969594X.2014.990416. 
Xiao, Yangyu. 2017. "Formative Assessment in a Test-Dominated Context: How Test Practice Can Become More Productive." Language Assessment Quarterly 14 (4): 295-311. https://doi.org/10.1080/15434303.2017.1347789.

Xiao, Yangyu, and Min Yang. 2019. "Formative Assessment and Self-Regulated Learning: How Formative Assessment Supports Students' Self-Regulation in English Language Learning." System 81:39-49. https://doi.org/10.1016/j.system.2019.01.004.

Yin, Xinying, and Gayle A. Buck. 2019. "Using a Collaborative Action Research Approach to Negotiate an Understanding of Formative Assessment in an Era of Accountability Testing." Teaching and Teacher Education 80:27-38. https://doi.org/10.1016/j.tate.2018.12.018.

\section{ABOUT THE AUTHOR}

Ruth Nanjekho Wqfubwa: PhD student, Doctoral School of Educational Science, University of Szeged, Szeged, Hungary 


\section{The International Journal of Assessment and}

Evaluation is one of ten thematically focused

journals in the collection of journals that support

The Learner Research Network - its journals,

book series, conference, and online community.

The journal investigates the dimensions of

educational measurement.

As well as articles of a traditional scholarly type, this journal invites presentations of practice-including documentation of measurement practices and exegeses of the effects of those practices.

The International Journal of Assessment and Evaluation

is a peer-reviewed, scholarly journal. 